Egyptian Journal of Aquatic Biology \& Fisheries

Zoology Department, Faculty of Science,

Ain Shams University, Cairo, Egypt.

ISSN $1110-6131$

Vol. 25(4): 767 - 783 (2021)

www.ejabf.journals.ekb.eg

\title{
Effects of prebiotic and molasses on water quality, growth and survival of Metapenaeus affinis and Macrobracium nipponense in vitro, without changing water or adding pellets
}

\section{Tariq H. Y. Al-Maliky*1, Anwar M. J. Al-Maliky², Gazi M. J. Al-Maliki ${ }^{1}$ and Chris A. Boyd ${ }^{3}$}

1.Marine Biology Department, Marine Science Centre, University of Basrah, Basrah, Iraq.

2.Biology Department, College of Education for pure science, University of Basrah, Basrah, Iraq. 3.Department of Biological and Environmental Science, Troy University. USA.

* Corresponding author: tariq.yasien@uobasrah.edu.iq

\section{ARTICLE INFO}

Article History:

Received: April 8, 2021

Accepted: July 29, 2021

Online: Aug. 30, 2021

Keywords:

Macrobracium

nipponense,

Metapenaeus affinis,

Probiotic,

Rearing.

\section{ABSTRACT}

In Iraq, for the first time, rearing juveniles of two species of shrimps, Metapenaeus affinis and Macrobracium nipponense in vitro with the addition of the Probiotic, AquaStar-PondZyme, BI, and molasses has taken place. Various environmental parameters were measured for the in vitro water samples; the results were as follows; temperature: $24-27{ }^{\circ} \mathrm{C}, \mathrm{Ph}$ : 7-8, salinity: 12-17\%, dissolved oxygen: 5-6 $\mathrm{mg} \bullet \mathrm{L}-1$, ammonia: 0.170 $0.200 \mathrm{mg} \bullet \mathrm{L}-1$ and Nitrate: $6-9 \mathrm{mg} \bullet \mathrm{L}-1$. The growth analysis for $M$. affinis and $M$. nipponense were as follows: initial weight (gm) $3.442 \pm 0.368$ and $0.127 \pm 0.015$, while final weight $(\mathrm{gm})$ was $4.454 \pm 0.844$ and $0.217 \pm$ 0.032 , specific growth rate $(\mathrm{SGR})(\% \bullet$ day-1) $21.21 \pm 4.02,3.460 \pm 2.639$, with the two species having similar survival (\%) $93.330 \pm 11.750$, respectively, over a 21-day period. Statistical analysis of $M$. affinis shrimp showed significant differences $(\mathrm{p}<0.05)$ between the rates of both initial and final weights, while there were no differences among the weight rates during other periods. The $M$. nipponense, on the presence of significant differences $(\mathrm{p}<0.05)$ between the rates of the final weights and both rates of primary and other periods weights, did not show significant differences ( $\mathrm{p}$ > 0.05). In addition, six genera (from it species) of bacteria were recorded with a density of CFU・mL-100; and arranged by density as follows; Bacillus subtilis, Enterococcus spp., Streptococcus spp., Faecal coliforms, Escherichia coli, Staphylococcus spp. on shrimp cultivated; M. affinis and M. nipponense, respectively.

\section{INTRODUCTION}

Lilly and Stillwell (1965) identified probiotics when introduced and produced from microorganisms, serving to aid in prolonging the growth stage in other species. Fuller (1989) formulated an important definition of probiotics as a living microbial food supplement beneficial to the host (human or animal). Addingly, probiotics are useful for improving the microbial balance of the body. Probiotics were also defined by a team of 
experts from the Food and Agriculture Organization of the United Nations (FAO) as living microorganisms, which when consumed in sufficient quantities, they provide a health help for a host (FAO, 2001). Verschuere et al. (2000) suggested that probiotics are defined as living microbial additives that facilitate a beneficial effect on the host by modifying the organisms microbial community associated with the host, by improving optimal use of feed and enhancing its nutritional value by enhancing the host's response to disease, or via improving the quality of the surrounding environment. Eminently, probiotics simplify the effective use of nutrients and minerals from feeds used by the host. Probiotics were derived from the Latin word PRO, and the Greek word BIOS, which means intended a life (Zivkovic, 1999). Lazado and Caipang (2014) proposed an expanded definition of probiotics stating that, probiotics are composed of either living, perished, or components of microorganisms that operate under various working patterns to produce useful effects for the host and his environment; and this applies to both fish and shrimp production practices.

Until recently, probiotics were considered a disease-controlling agent in shrimp culture, as probiotics have been proven to demonstrate their ability to directly inhibit the growth, spread pathogens and stimulate the dominance of these useful microorganisms within a host (Chythanya \& Karunasagar, 2002; Preetha et al., 2007; Lazado et al., 2010; Lazado et al., 2011; Lazado \& Caipang, 2014).

The effect of probiotics on shrimp growth performance was observed in Fenneropenus indicus, fed with a Bacillus sp. probiotic mixture (Ziaei-Nejad et al., 2006). The feed conversion rate and specific growth rate were found significant in the group receiving probiotics feed in the control group. On the other hand, on using Bacillus isolates from the host's intestine, morphometric changes were observed in Macrobrachium rosenbergii fed with probiotics. Besides weight gain, the length of the shrimp body that fed on probiotics was significantly longer than that in the control group (Deeseenthum et al., 2007).

The most common method of applying probiotics to aquaculture operations is through food supplements (Huang et al., 2006; Gomes et al., 2009). Their beneficial effect is interpreted as the result of an increase in appetite or an improved food digestibility.

Fernandez et al. (2011) studied Penaeus indicus nutrition on probiotics represented by lactic acid bacteria, which helped to improve digestibility by approximately 20\%. Furthermore, Martinez Cruz et al. (2012) found that the probiotics that are most commonly used in shrimp aquaculture production through feed supplements belong to the genus Bacillus sp. This study has shown that Litopenaeus vannamei phenotypic digestibility is most affected by Bacillus sp. Several studies of probiotics were applied to many types of shrimps, and monitored an increase in their weights; Penaeus monodon (Rengpipat et al., 2003; Soundarapandian \& Sankar, 2008), Penaeus vannamei (Gullian et al., 2004; Wang \& Gu, 2010), Marsupenaeus japonicus (Dong et 
al., 2013), M. Rosenbergii (Mujeeb Rahiman et al., 2010) and Farfantepenaeus brasiliensis (De Souza et al., 2012).

This is especially important to present the concepts of application to bacterial feasibility in culture waters as these beneficial microorganisms are able to offer their benefits in many mediums (Gomez-Gil et al., 2000; Makridis et al., 2005; Lazado \& Caipang, 2014). Through trends of a recent research for improving the environmental sustainability of aquaculture, probiotics have been found to positively impact the sustainability of this industry as evidenced by many papers that assessed their many useful properties, importance and application (Guo et al., 2009; Van Hai \& Fotedar, 2010; Lazado \& Caipang, 2014). Lazado and Caipang (2014) illustrated how interferences of the aquatic environment led to the leading viewpoint about probiotics definitions as being controversial and can only be applied to each case separately. All previous definitions of probiotics were the most commonly cited and have been widely referred to in both human and veterinary studies for several years. Probiotic research expanded into aquaculture in the late 1990s. This approach was invoked when antibiotic alternatives became necessary in attempts to combat fish and shrimp diseases that were becoming more persistent in aquaculture farms throughout the world due to aquaculture intensification (Boyd \& McNevin, 2015).

The current study used the two species of shrimp, Metapenaeus affinis and Macrobrachium nipponense, live together in Iraqi inland waters, Al-Mashab - Hammar Marsh with a commercial presence of M. affinis in Iraqi marine waters. Previous studies conducted on them are enormous (Al-Maliky et al., 2009, 2019; Al-Maliky, 2013; AlMaliki et al., 2015; Al-Daraji et al., 2019).

This study was conducted with the aim of raising two species of shrimp this through using the new formulated probiotic AquaStar-PondZyme along with the incorporation of molasses into culture systems to reduce breeding costs while improving shrimp productivity.

\section{MATERIALS AND METHODS}

\section{Usage of probiotics}

A pre-made probiotic and molasses mix was generated according to Maia $\boldsymbol{e t} \boldsymbol{a l}$. (2016) who added the mixture to shrimp aquaculture ponds in order to constantly stimulate the shrimp immune and digestive systems through adding a source of carbohydrates with continuous ventilation. Hence, a useful gel probiotic mass was created and used by the shrimp juveniles along with nutrition provided by the molasses. This is what the current experiment was based on; through applying a biological treatment powder (Biomin, Naturally forward, AquaStar-PondZyme) (BI), (Made in Singapore) that improves difficult biotic pool conditions (Aquaculture, 2014). One gram of BI was added to each pond, which is twice the required amount according to the instructions 
provided on the BI label. Molasses (Al-Faihaa-Hilla-Iraq) was added to the pond water using a rate of $1 \mathrm{ml}$ of molasses $\mathrm{L} \mathrm{H}_{2} \mathrm{O}^{-1}$ daily. The feeding was twice a day at 9 am and $1 \mathrm{pm}$.

\section{Rearing of shrimp}

Shrimp juveniles were collected from river water samples of Al-Meshab area near Al-Hammar Marshes, North of Basrah in Iraq. Samples were transferred to the aquaculture Vitro (laboratory) in Marine Biology Department Basrah University, Basrah, Iraq, where the project team selected the best juveniles from the two species of shrimp samples of different growth stages; $M$. affinis $(3.442 \pm 0.368 \mathrm{gm})$ and $M$. nipponense $(0.127 \pm 0.015 \mathrm{gm})$. Each species of shrimp were placed in separate mesocosms in vitro, with dimensions $30 \times 20 \times 15 \mathrm{~cm}$. Three replicates of five shrimps for each species were put into each mesocosm. The mesocosms were covered with nets to prevent shrimp from jumping out (Fig. 1). The water source of the experiment was household chlorinated wastewater used after a three-day acclimatization period.

Using a sensitive, balance the weight of the shrimp was recorded. Survival rates were calculated based on the procedure presented by Esparza-Leal et al. (2010). Ammonia, nitrate, salinity, dissolved oxygen, temperature, and $\mathrm{pH}$ were measured throughout the experiment (laboratories of the Marine Chemistry Department, MSC).

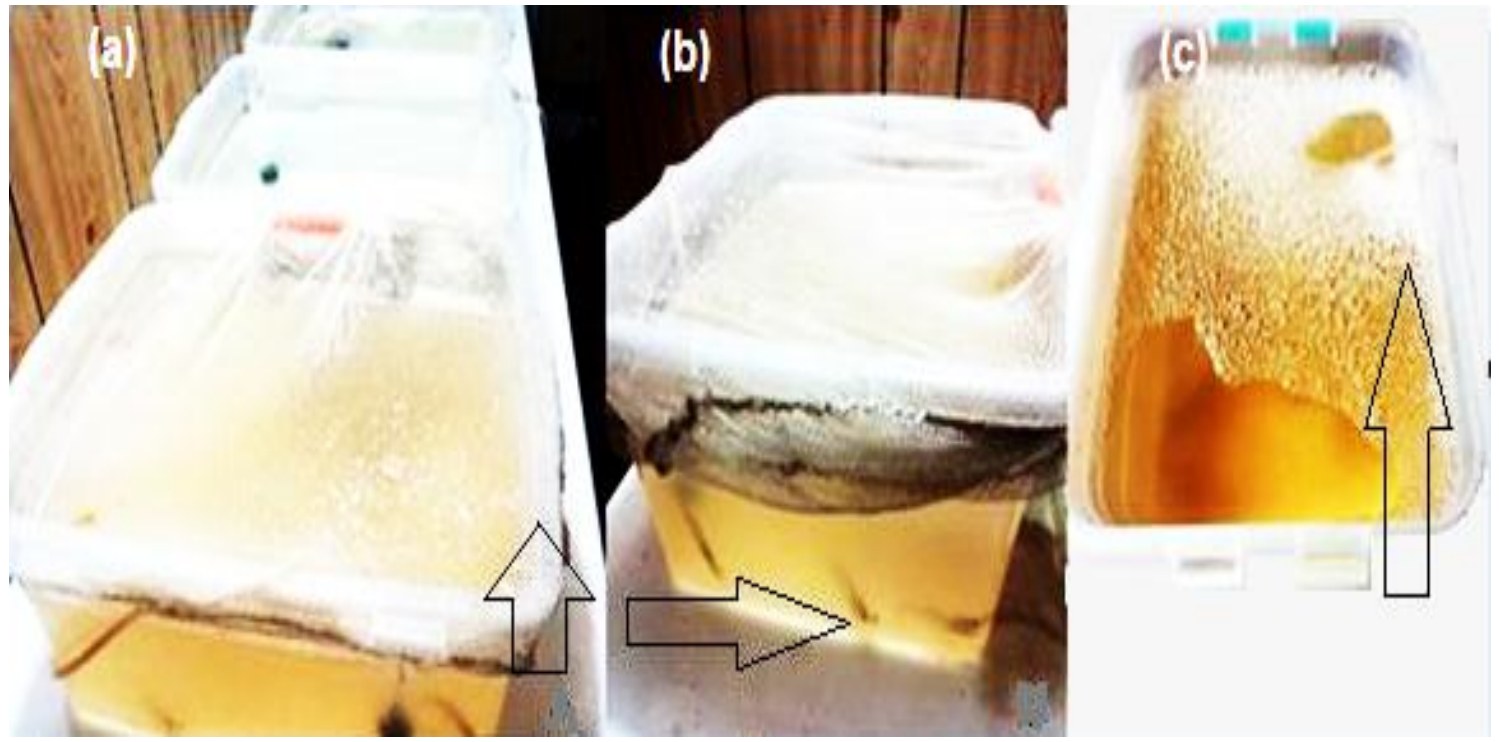

Fig. 1: Shrimp mesocosm (a) in vitro, shrimp juveniles in one of the mesocosms (b), surface water appearance after adding a probiotic with molasses (c).

\section{Bacterial isolation}

Serial dilution method was followed for bacterial isolation using nutrient agar medium and shrimp muscle samples dissected under sterilization; with the homogeneous muscle tissues being used for the tests. The selected muscle tissue samples were diluted 
homogeneously into a serial form and distributed separately among the nutrient agar plates $(n=72)$ while preserving a single plate as control without a sample, each agar plate was incubated at $37^{\circ} \mathrm{C}$ for 24 to $48 \mathrm{~h}$ to monitor and grow bacterial colonies. Post incubation; the total number of the colony-forming unit (CFU) for each plate was recorded and the suppressive colonies which were subcultures were identified. The average bacterial number for each group of duplicates expressed as $\mathrm{CFU} \cdot \mathrm{mL}^{-100}$ of homogeneous tissue was reported (Higgins \& VanderGheynst, 2014).

\section{Identification of isolated bacteria}

The isolated bacteria were identified as follows: morphological and biochemical properties were recorded for the individual colony. The individual colony was transferred to the nutrient agar. Isolates underwent various biochemical tests: gram staining movement, indole, methyl, calculated membrane, catalase, nitrates and carbohydrate condensation. This study was carried out in-vitro at the Department of Marine Biology, Biotechnology laboratory.

\section{Statistical analysis}

The results were shown as mean $\pm \mathrm{SD}$ of triple measurements. The evaluation of the effect of using probiotics with molasses was based on the growth of two species of juvenile shrimp at different age groups, separately each for three weeks. Using SPSS version 15, a one-way ANOVA was used to analyze treatments to determine significant levels below 0.05, LSD.

\section{RESULTS AND DISCUSSION}

Whereas the ammonia and nitrate ranges were different in some concentrations of shrimp, the assessment of water quality in shrimp ponds is very important in determining the environmental conditions necessary to combat disease (Heenatigala \& Fernando, 2016). Aquaculture producers must keep these water quality parameters within the optimal concentration ranges to prevent low oxygen fluctuations that tend to increase organismal stress that would prevent optimal growth rates. Many aquaculture producers work on the biological and environmental limits in order to improve yields. Reducing the FCR is one of the most important practices that aquaculture producers can implement at the farm level in order to reduce operating costs while reducing nutrient loading. The addition of probiotics can support FCR reduction and biological stress. Temperatures were recorded within the appropriate range for shrimp growth with readings between 24 to $27^{\circ} \mathrm{C}, \mathrm{pH}$ ranged from 7 to 8 , salinity levels were relatively high (between 12 and $17 \%$ ), and dissolved oxygen concentrations were within acceptable ranges; between 5 and $6\left(\mathrm{mg} \cdot \mathrm{L}^{-1}\right)$ (Table 1$)$. These values were expected because the use of probiotics assists in improving water quality properties. In the present study, the values of the 
environmental factors, including temperature, $\mathrm{pH}$, dissolved oxygen and salinity were within the permissible ranges in shrimp rearing ponds (Legarda et al., 2018). growth (Maia et al., 2016). This difference may be due to the short period of the present trial compared to the length of the trial period of the comparative study.

Shailender et al. (2012) presented the following environmental conditions that typically yielded maximum shrimp production and growthas follows: $26-30^{\circ} \mathrm{C} ; 3.6-6.5$ $\mathrm{mg} \cdot \mathrm{L}^{-1}$ oxygen; $10-20,10-35 \%$ salinity; 6.7- $8.7 \mathrm{pH}$.

Table 1. Some important environmental factors recorded in mesocosms of shrimp juveniles M. affinis and M. nipponense over a period of 21days

\begin{tabular}{lc}
\hline Factor Environmental & Value \\
\hline Temperature $\left({ }^{\circ} \mathrm{C}\right)$ & $24-27$ \\
$\mathrm{pH}$ & $7-8$ \\
Salinity $(\%)$ & $12-16$ \\
Dissolved Oxygen $\left(\mathrm{mg} \cdot \mathrm{L}^{-1}\right)$ & $5-6$ \\
Ammonia $\left(\mathrm{mg} \cdot \mathrm{L}^{-1}\right)$ & $0.170-0.200$ \\
Nitrate $\left(\mathrm{mg} \cdot \mathrm{L}^{-1}\right)$ & $6-9$ \\
\hline
\end{tabular}

This study was conducted within a short period of time. Positive indicators were addressed for growth and improvement of the health status of two types of shrimp of different ages after using the probiotic mixture with molasses for 21 days without either providing any other food source or replacing the experimental water. Dissolved oxygen with ranges between 3.6 to $6.5 \mathrm{mg} \cdot \mathrm{L}^{-1}$ plays an important role in shrimp growth and production through its direct impact on feed consumption and maturity. While, oxygen improves the solubility and availability of many nutrients. The symptoms of low levels of oxygen include a decrease in oxidation of oxidizing substances, increased biological stress, shrimp suffocation and poisoning, impaired metabolism, reduced growth rates, and consequently death if ever the oxygen concentrations did not return to normal ranges. Recorded ammonia levels, with ranges between $0.1-0.3 \mathrm{mg} \cdot \mathrm{L}^{-1}$, were within the normal range for optimal growth. Ammonia, in the presence of prebiotics, was later converted to nitrite and subsequentially to nitrate through the nitrification process (Shailender $\boldsymbol{e t}$ al., 2012). Recorded nitrate levels, ranging from 6 to $9 \mathrm{mg} \cdot \mathrm{L}^{-1}$, were within the normal range for optimal growth of aquaculture species (Boyd \& McNevin, 2015). 
Table 2. Some growth metrics for M. affinis and M. nipponense in probiotic mesocosms with molasses over 21 days (mean $\pm \mathrm{SD}$ )

\begin{tabular}{l|lc}
\hline \multirow{2}{*}{ Parameter } & \multicolumn{2}{c}{ Malue Means } \\
\cline { 2 - 3 } & \multicolumn{1}{c}{ M. affinis } & M. nipponense \\
\hline Initial weight $(\mathrm{g})$ & $3.442 \pm 0.368$ & $0.127 \pm 0.012$ \\
Final weight $(\mathrm{g})$ & $4.454 \pm 0.844$ & $0.217 \pm 0.026$ \\
${\text { SGR }\left(\% \cdot \text { day }^{-1}\right)}^{\text {Survival rates (SR) }(\%)}$ & $21.210 \pm 4.020$ & $3.460 \pm 2.639$ \\
& $93.330 \pm 11.550$ & $93.330 \pm 11.550$ \\
\hline
\end{tabular}

The results shown in Table (2) indicate that the Specific Growth Rate (SGR values were high in the lipid for shrimp M. affinis compared to the low values for oriental shrimp, M. nipponens. This may be due to the difference in initial stocking weights and the weight increase occurred in the first sampling and the second sampling/ final weight.

Sundaram et al. (2017) stated that the results of SGR minimal range were between $2-3$ for shrimp $P$. vannamei during feeding with probiotic additives, which bestowed a moderate increase in growth in shrimp farms. The bacteria were bacteriostatic and not pathogenic. They improved the growth of shrimp on the farm, meaning that they were able to produce extracellular materials and anti-pesticides. Beneficial microbes convey an antagonistic relationship with other pathogenic microorganisms through competitive exclusion once they find their optimal niche. A specific growth of $0.03 \%$ for the shrimp was also beneficial for probiotics for shrimp growth (Gatesoupe, 1999). Ghosh et al. (2016), in his probiotics' experiment on cunning shrimp, M. rosenbergii, reorted that the SGR was between 1-2, and the survival ratios were $90 \%$, growth increased from $1 \mathrm{~g}$ to $39-52 \mathrm{~g}$ during a 240-day rearing period in a treatment consisting mainly of fecal Streptococcus spp., Clostridium butyricum, Bacillus mesentericus, protease, lipase, and brewer's yeast. An increase in the survival rates of shrimp $P$. vannamei in farms that use probiotics was observed due to the improvement of water quality, for example, Bacillus $s p$. were used to dissolve the organic matter into simpler substances, which helps to improve the quality of pond water, and thus, decrease in the levels of ammonia, nitrite, and nitrate (Sundaram et al., 2017).

Won et al. (2020) used several probiotics, including Bacillus subtilis, Pediococcus pentosaceus and Lactococcus latis to assess their effect on the growth and survival of the artistic shrimp, L. vannam, compared to the initial weight rates, while they reached final weight rates and specific growth rates of $3 \%$. day ${ }^{-1}$, and their survival rates increased by $88 \%$ during an eight-week trial. 


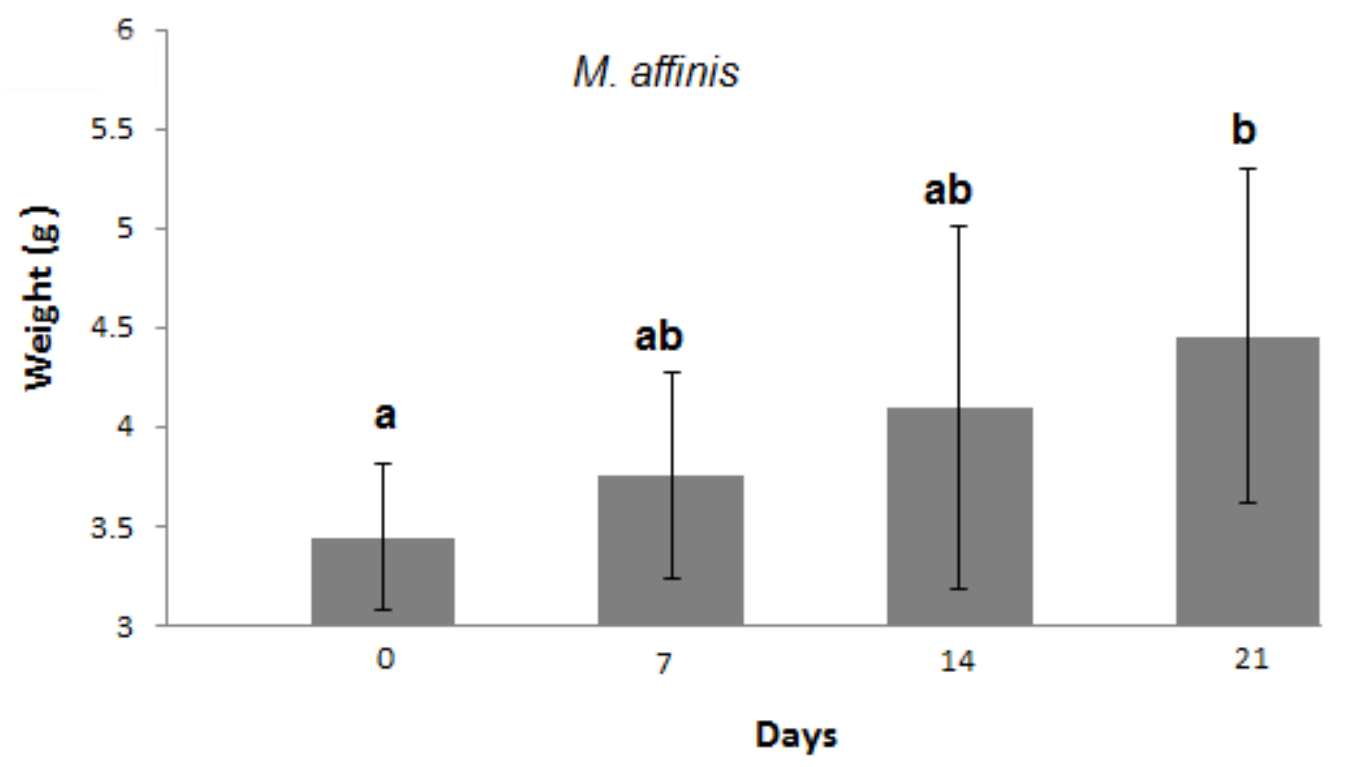

Fig. 2. Shrimp growth rates of M. affinis in probiotic mesocosms with molasses during 21 days (mean $\pm \mathrm{SD})$

error bars represent the standard deviation, different letters above the error bar for a large difference ( $\mathrm{P}$ $<0.05$ ), (between initial weight rates and final weight rates), there are no letters above the error bar, so there are no differences $(\mathrm{p}>0.05)$ of weights during other periods.

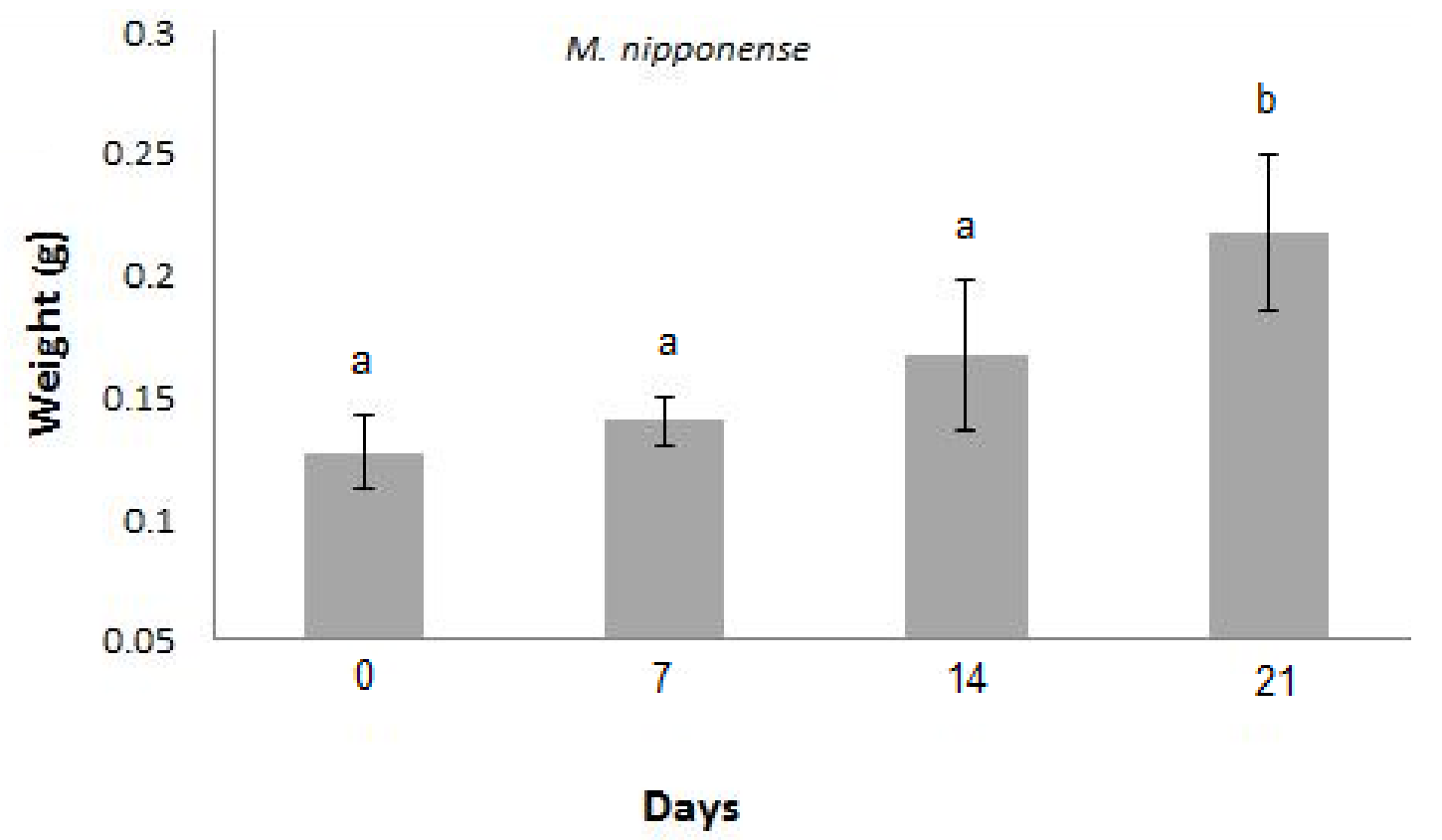

Fig. 3. Shrimp growth rates of $M$. nipponense in probiotic mesocosms with molasses during 21 days (mean $\pm \mathrm{SD})$. 
From Figs. ( $2 \& 3)$, a weekly weight gain was noticed during the study periods for both species of shrimp. Through the statistical analysis of the results of M. affinis, significant differences were determined only between final weight rates $(4.454 \mathrm{~g})$ and primary weight rates (3.442 g), and no significant differences were detected between them and the study periods on the first $(3.752 \mathrm{~g}$ ) and second weeks (4.098 g). While, with respect to shrimp $M$. nipponense, the presence of significant differences were monitored between the final weight rates and all weight rates during the other study periods. This analysis demonstrated the effect of probiotics on the two species of shrimp, with $M$. nipponense being more affected throughout all periods of the study, while probiotic treatment had a delayed but more robust effect on $M$. affinis. This means that M. affinis was more positive for probiotics recording fast growth compared to $M$. nipponense.

Although rearing two different species presents different needs, the shrimp adaptation to the new environment may be due to the reproduction of biomass resulting from the addition of the molasses mixture with probiotics with continued ventilation. Besides, it was followed by an increase in growth throughout the experiment, with the highest increase in growth rates as final weights, because some of the existing shrimps were more suitable for their growth. Unlike some individual species that have not been adapted to the new environment; this is normal for growth among individuals of shrimp. Vieira et al. (2010) found that there was no difference in survival or growth rates between cultured shrimp with the presence of probiotics by Lactobacillus plantarum and their absence. Other authors have also stated that probiotics have the potential to improve the prawn immune system and reduce the multiplication of pathogenic bacteria through competition for food and space and could increase seed (larvae) quality (Shafat 2018; Jamal et al., 2019; Won et al., 2020).

Table 3. A number of bacterial isolated (CFU.mL-100) on shrimp $M$. affinis and $M$. nipponense and in the water of rearing during the experimental period

\section{No. of Bacteria in ponds of shrimp}

\section{Bacterial isolated}

M. affinis

M. nipponense

\begin{tabular}{ccccc}
\cline { 2 - 5 } & on shrimp & in water & on shrimp & in water \\
\hline Bacillus subtilis & 60 & 100 & 65 & 100 \\
Enterococcus spp. & 40 & 80 & 50 & 85 \\
Streptococcus spp. & 30 & 70 & 35 & 80 \\
Staphylococcus spp. & 20 & 50 & 30 & 55 \\
Fecal coliform & 20 & 80 & 20 & 70 \\
Escherchia coli & 20 & 70 & 20 & 65 \\
\hline The total & 190 & 450 & 220 & 455 \\
\hline
\end{tabular}


Six bacteria genus (species) are listed in probiotic mesocosms in Fig. (3) and Table (3). They were observed on the shrimp and found at a lower concentration compared to their water presence, and in both cases, they were within the acceptable density ranges. The pathogenic load in the shrimp aquaculture system was maintained below 1,000 $\mathrm{CFU} \cdot \mathrm{mL}^{-1}$ for optimal shrimp growth and through the need to control microbial mass (Ganesh et al., 2010).
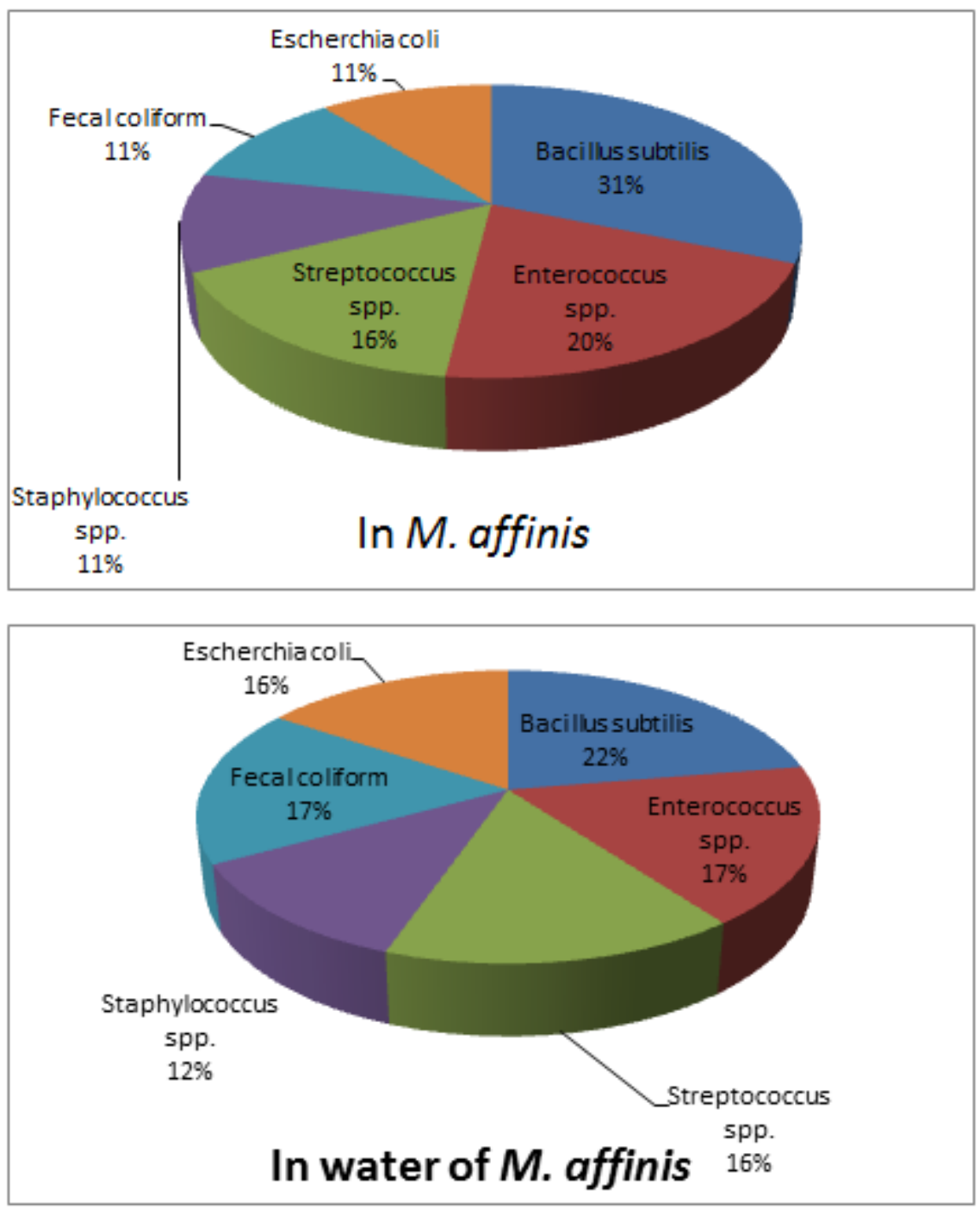

Figure 4. The ratios of some species of bacteria in rearing of shrimp $M$. affinis during the experiment period 21 days. 

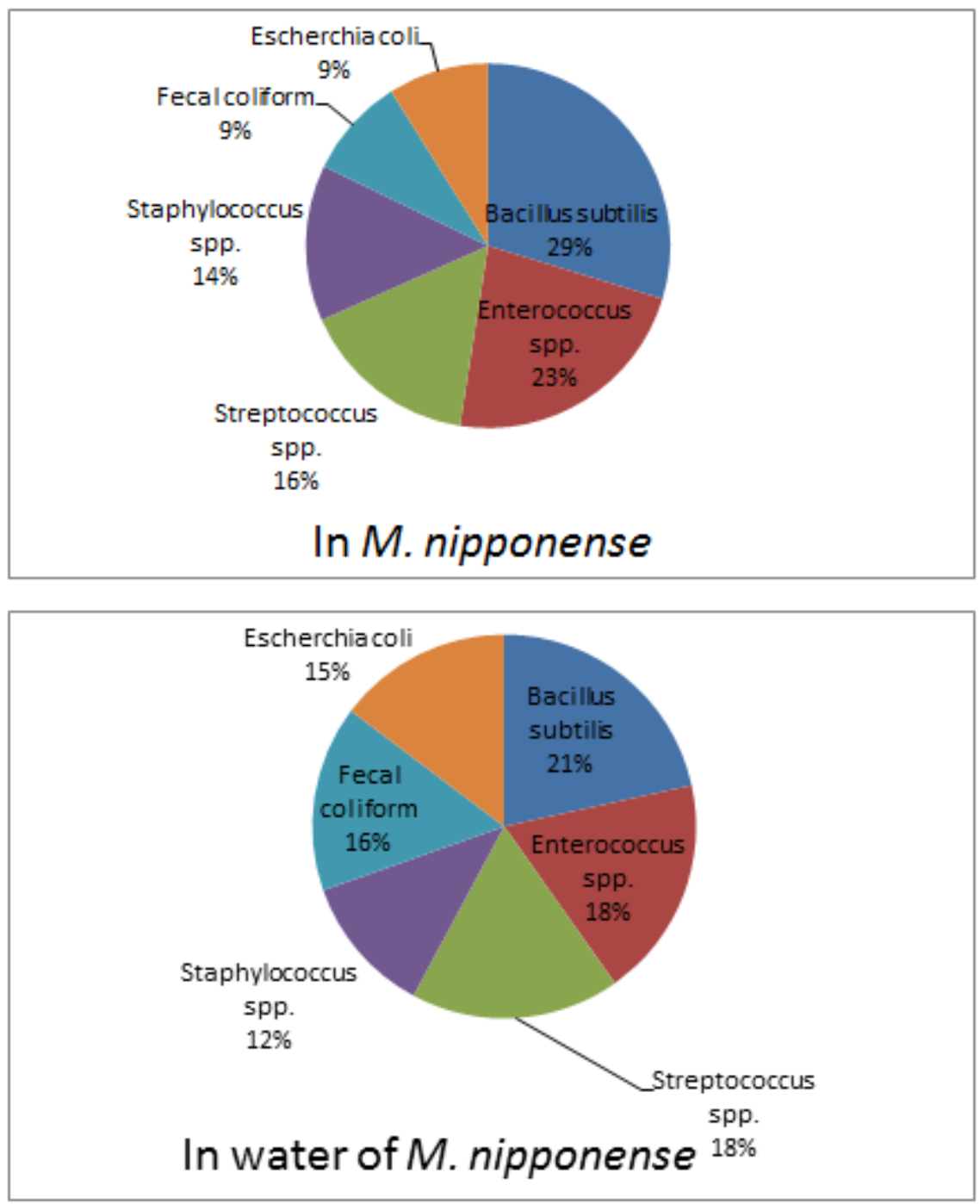

Fig. 5. The ratios of some species of bacteria in rearing of shrimp M. nipponense during the experimental period of 21 days.

The use of probiotics is a successful method of antibiotics because of its environmentally friendly natured, and its efficiency in promoting the growth of shrimp and increasing its resistance to diseases, immune formation, and ability to optimize other aquaculture culture methods is inspiring (Shafat, 2018).

The probiotic additions had an effective result on this system through using molasses for the purpose of increasing carbohydrates for providing energy and other metabolic needs for shrimp, while adding the BI powder, rich in bacteria, vitamins and other nutrients proved very influential for the production of biomass. Overall, experimental results depicted that shrimp adolescents grew to optimal weights without using a dietary feed within 21 , but rather, by only using molasses and BI powder. 
Won et al. (2020) stressed that there are many applications with respect to probiotics added to shrimp food and were proved useful for growth, immune response and resistance to diseases. Moreover, probiotics increased activation of the digestive enzyme in the intestines of shrimp, and thus, promoted protein, starch, and fats. While Jamal et al. (2019) mentioned, the probiotics work to inhibit the pathogens and promote the ability to modify the immune system. In addition, the afore-mentioned authors proved that the use of Bacillus spp. was beneficial in improving the quality of the water system by converting organic matter into carbon dioxide.

The use of probiotics is beneficial to shrimp farms as they help improving fungal community structure which improves culture species immunity and production of anticlotting protein cellular components, among others, thus enhances shrimp disease resistance (Zorriehzahra et al., 2016).

\section{CONCLUSION}

The results provided a clear picture that the selected two species of shrimp grown under laboratory conditions with the addition of probiotic with molasses diet furnished a stress test to determine its efficacy. Through the statistical analysis, it was found that shrimp M. affinis had a better response to growing under probiotic conditions compared to shrimp M. nipponense.

The increase in shrimp biomass improved with the presence of these additives and without the addition of a feed-based diet. It is concluded, without doubt, that the results would be as good or better than those of the present study, if ever performed under these same conditions with minimal additions of the feed-based diet to shrimp culture systems. This conclusion is important for calculations of the economic feasibility of establishing a shrimp farm in the future as in Iran. Many types of bacteria were also diagnosed in vats, which is an expected result of the fact that probiotics contain many different types of bacteria, so it was necessary to identify these species, their density, and other factors. Finally, this article would be encouraging for future applied studies by farmers and investors in this region, which lacks shrimp farm expansion and investing.

\section{ACKNOWLEDGMENTS}

We thank all those who supported us from the biology department and the laboratories of the chemistry department at our center (MSC).

\section{REFERENCES}

Al-Daraji, S. A.M.; Jassim, A.A.R.; Al-Maliky, T.H.Y. and Majid, AABannai, M.A.A.Z. (2019). EXPERIMENTAL STUDY OF PREDATION BEHAVIOR OF THE 
SHRIMP MACHROBRACHIUM NIPPONENSE (DE HAAN, 1849) ON GRASS CARP CTENOPHARYGODON IDELLA VAL., 1844. CnR's Inter. J. of Soci.and Sci. Res., 5 (2): $10 \mathrm{pp}$.

Al-Maliky, T. H. Y. (2013). Mannal and characters of common shrimps species in Southern Iraqi waters. Publications of the Marine Science Center - University of Basra Iraq. Deposit number in the House of Books and Documents in Baghdad 756 for the year 2013. 192 pp.

Al-Maliky, T. H. Y.; Ali, M.H. and Al-Nor, S.S. (2009). Comparison of the growth rates of Jinga Shrimp Metapenaeus affinis (H. Milne Edwards, 1837) In different types of Aquaculture Systems. A thesis Submitted to the College of Agriculture - University of Basrah In Partial Fulfillment of the Requirements for the degree of Master of Science in Fisheries Resources. 108 pp.

Al-Maliky, T. H. Y.; Ali, M.H. and Al-Nor, S.S. (2019). Effect of different temperatures on food consumption of juveniles shrimp Metapenaeus affinis (H. Milne Edwards, 1837). Arthrop., 8(1): 32-37.

Al-Maliky, T. H. Y.; Ali, M.H. and Hashim, A.A. (2015). Study of Some Biological and Ecological Aspects, Aquaculture and Breeding Methods of Oriental Prawn Macrobrachium nipponense (De Haan, 1849) In Basrah, Iraq. A Thesis Submitted to the College of Agriculture, University of Basrah As A Partial Fulfillment of the Requirements for the Degree of Doctorate of Philosophy in Fisheries and Marine Resources (breeding \& feeding of shrimps), $158 \mathrm{pp}$.

Aquaculture, (2014). Science and solutions aquaculture is a quarterly publication of BIOMIN Holding GmbH, distributed free of charge to our customers and partners. Each issue of Science and Solutions Aquaculture presents topics on the most current scientific insights in aquatic nutrition and health. 12 p. http://magazine.biomin.net.

Boyd, C.E. and McNevin, A.A. (2015). Aquaculture, Resource Use, and the Environment. Wiley-Blackwell, Hoboken, New Jersey, 337 pp.

Chythanya, R. and Karunasagar, I. (2002). Inhibition of shrimp pathogenic vibrios by a marine Pseudomonas I-2 strain. Aquaculture. 208: 1-10.

De Souza, D.M.; Suita, S.M.; Leite, F.P.L.; Romano, L.A.; Wasielesky, W. and Ballester, E.L.C. (2012). The use of probiotics during the nursery rearing of the pink shrimp Farfantepenaeus brasiliensis (Latreille, 1817) in a zero exchange system. Aquacult. Res., 43: 1828-1837. 
Deeseenthum, S.; Leelavatcharamas, V. and Brooks, J.D. (2007). Effect of feeding Bacillus sp. as probiotic bacteria on growth of giant freshwater prawn (Macrobrachium rosenbergii (de Man). Pakistan J. Biol. Sci., 10: 1481-1485.

Dong, H.b.; Su, Y.q.; Mao, Y.; You, X.x.; Ding, S.x. and Wang, J. (2013). Dietary supplementation with Bacillus can improve the growth and survival of the kuruma shrimp Marsupenaeus japonicus in high-temperature environments. Aquac. Int., 1-11.

Esparza-Leal, H.M.; Ponce-Palafox, J.T.; Valenzuela Quiñonez, W.; ArredondoFigueroa, J.L. and GarciaUlloa, M. (2010). Effects of density on growth and survival of juvenile Pacific white shrimp, Penaeus vannamei, reared in low-salinity well water. J. Wo. Aquac. Soc., 41(4): 648-654.

FAO, (2001). Report of a Joint FAO/WHO expert consultation on evaluation of health and nutritional properties of probiotics in food including powder milk with live lactic acid bacteria, Córdoba, Argentina.

Fernandez, R.; Sridhar, M. and Sridhar, N. (2011). Effect of lactic acid bacteria administered orally on growth performance of Penaeus indicus (H. Milne Edwards) juveniles. Res. J. Microbiol., 6: 466-479.

Fuller, R. (1989). Probiotics in man and animals. J. Appl. Bacteriol., 66: 365-378.

Ganesh E.A.; Das, S.; Chandrasekar, K.; Arun, G. and Balamuruga, S. (2010). Monitoring of total heterotrophic bacteria and Vibrio spp. In an aquaculture pond. Cur. Res. Journal Biol. Sci., 2(1): 48-52.

Gatesoupe, F.J. (1999). The use of probiotics in aquaculture. Aquacul., 180: 147-165.

Ghosh, A.K.; Bir, J.; Azad, Md.A.K.; Hasanuzzaman, A.F.Md.; Islam, Md.S. and Hug, K.A. (2016). Impact of commercial probiotics application on growth and production of giant Freshwater prawn (Macrobrachium Rosenbergii De Man, 1879). Aquacult. Rep., 4: 112-117.

Gomes, L.C.; Brinn, R.P.; Marcon, J.L.; Dantas, L.A.; Brandão, F.R.; De Abreu, J.S.; Lemos, P.E.M.; McComb, D.M. and Baldisserotto, B. (2009). Benefits of using the probiotic Efinol®L during transportation of cardinal tetra, Paracheirodon axelrodi (Schultz), in the Amazon. Aquacult. Res., 40: 157-165.

Gomez-Gil, B.; Roque, A. and Turnbull, J.F. (2000). The use and selection of probiotic bacteria for use in the culture of larval aquatic organisms. Aquacult., 191: 259270. 
Gullian, M.; Thompson, F. and Rodriguez, J. (2004). Selection of probiotic bacteria and study of their immunostimulatory effect in Penaeus vannamei. Aquacult., 233: 1-14.

Guo, J.J.; Liu, K.F.; Cheng, S.H.; Chang, C.I.; Lay, J.J.; Hsu, Y.O.; Yang, J.Y. and Chen, T.I. (2009). Selection of probiotic bacteria for use in shrimp larviculture. Aquacult. Res., 40: 609-618.

Heenatigala, P.P.M. and Fernando, M.U.L. (2016). Occurrence of bacteria species responsible for vibriosis in shrimp pond culture systems in Sri Lanka and assessment of the suitable control measures. Sri Lanka J. Aquat. Sci., 2 (1): 1-17.

Higgins, B.T. and VanderGheynst, J.S. (2014). Effects of Escherichia Coli on Mixotrophic Growth of Chlorella Minutissima and Production of Biofuel Precursors. PLoS One. 7; 9(5): e96807. DOI: 10.1371/journal.pone.

Huang, X.; Zhou, H. and Zhang, H. (2006). The effect of Sargassum fusiforme polysaccharide extracts on vibriosis resistance and immune activity of the shrimp, Fenneropenaeus chinensis. Fis. Shell. Imm., 20: 750-757.

Jamal, M.T.; Abdulrahman, I.A.; Mamdouh Al Harbi, M. and Chithambaran, S. (2019). Probiotics as alternative control measures in shrimp aquaculture: A review. J. Appl. Biol. Biotechnol., 7(3): 69-77.

Lazado, C.C. and Caipang, C.M.A. (2014). Atlantic cod in the dynamic probiotics research in aquaculture. Aquacult., 424-425: 53-62.

Lazado, C.C.; Caipang, C.M.A.; Brinchmann, M.F. and Kiron, V. (2011). In vitro adherence of two candidate probiotics from Atlantic cod and their interference with the adhesion of two pathogenic bacteria. Vet. Microbiol., 148: 252-259.

Lazado, C.C.; Caipang, C.M.A.; Rajan, B.; Brinchmann, M.F. and Kiron, V. (2010). Characterization of GP21 and GP12: Two potential probiotic bacteria isolated from the gastrointestinal tract of Atlantic cod. Probiotics Antimicrob Prote., 2: 126-134.

Legarda, E.C.; Barcelos, S.S.; Redig, .C.; Ramírez, N.C.B.; Guimarães, A.M.; Santo, C.M.E.; Seiffert, W.Q. and Vieira, F.N. (2018). Effects of stocking density and artificial substrates on yield and water quality in a biofloc shrimp nursery culture. Rev. Brasi. de Zootec., 47: e20170060. doi: 10.1590/rbz4720170060.

Lilly, D.M. and Stillwell, R.H. (1965). Probiotics: Growth-promoting factors produced by microorganisms. Scien., 147: 747-748. 
Makridis, P.; Martins, S.; Vercauteren, T.; Van Driessche, K.; Decamp, O. and Dinis, M.T. (2005). Evaluation of candidate probiotic strains for gilthead sea bream larvae (Sparus aurata) using an in vivo approach. Lett. Appl. Microbiol., 40: 274-277.

Maia, E.P.; Modesto, G.A.; Brito, L.O.; Galvez, A.O. and Gesteira, T.C.V. (2016). Intensive culture system of Litopenaeus vannamei in commercial ponds with zero water exchange and addition of molasses and probiotics. Rev. Biol. Marina Ocean., 51(1): 6167.

Martinez Cruz, P.; Ibañez, A.L.; Monroy Hermosillo, O.A. and Ramirez Saad, H.C. (2012). Use of probiotics in aquaculture. International Scholarly Research Network. ISRN Microbiol., 13p. doi:10.5402/2012/916845.

Mujeeb Rahiman, K.M.; Jesmi, Y.; Thomas, A.P. and Mohamed Hatha, A.A. (2010). Probiotic effect of Bacillus NL110 and Vibrio NE17 on the survival, growth performance and immune response of Macrobrachium rosenbergii (de Man). Aquac. Res., 41(9): 120-134.

Preetha, R.; Jayaprakash, N.S. and Bright Singh, I.S. (2007). Synechocystis MCCB 114 and 115 as putative probiotics for Penaeus monodon post-larvae. Dis. Aquat. Org., 74: 43-247.

Rengpipat, S.; Tunyanun, A.; Fast, A.W.; Piyatiratitivorakul, S. and Menasveta, P. (2003). Enhanced growth and resistance to Vibrio challenge in pond-reared black tiger shrimp Penaeus monodon fed a Bacillus probiotic. Dis. Aquat. Org., 55:169-173.

Shailender, M.; Suresh, B.Ch.; Srikanth, B.; Banggarraju, P.; Siva, K.G. and Jayagopal, P. (2012). Effect of Probiotics on Growth and Survival of Penaeus Monodon (Fabricius, 1798) Post Larvae Infected With Swollen Hindgut Syndrome (SHG) With Better Management Practices. J. Pharm. Biol. Sci., 3 (4): 33-40.

Shefat, S.H.T. (2018). Use of Probiotics in Shrimp Aquaculture in Bangladesh. ACTA Sci. Microbiol., 1(11); 8 pp.

Soundarapandian, P. and Sankar, S. (2008). Effect of probiotics on the survival and production of black tiger shrimp Penaeus monodon (Fabricius). Int. J. Zoo. Res., 4: 3541.

Sundaram, M.; Panigrahi, A.; Ganesh, J.; Rekha, P.N.; Sivagnanam, S.; Rajamanickam, S. and Gopal, C. (2017). Evaluation of different probiotic strains for growth performance and immunomodulation in Pacific white shrimp Penaeus vannamei Boone, 1931. Indian J. Fish., 64: 89-96. 
Van Hai, N. and Fotedar, R. (2010). A review of probiotics in shrimp aquaculture. J. Appl. Aquacult., 22: 251-266.

Verschuere, L.; Rombaut, G.; Sorgeloos, P. and Verstraete, W. (2000). Probiotic bacteria as biological control agents in aquaculture. Microbiol Mol. Biol. Rev., 64: 655671.

Vieira, F. N.; Buglione, C. C.; Mourino, J. P. L.; Jatobá, A.; Martins, M. L.; Schleder, D. D.; Andreatta, E. R.; Barraco, M. A. and Vinatea, L. A. (2010). Effect of probiotic supplemented diet on marine shrimp survival after challenge with Vibrio harveyi. Arqu. Brasil. Med. Vete. Zootec., 62: 631-638.

Wang, Y. and Gu, Q. (2010). Effect of probiotics on white shrimp (Penaeus vannamei) growth performance and immune response. Mar. Biol. Res., 6: 327-332.

Won, S.; Hamidoghli, A.; Choi, W.; Bae, J.; Jang, W.J.; Lee, S. and Bai, S.C. (2020). Evaluation of Potential Probiotics Bacillus subtilis WB60, Pediococcus pentosaceus, and Lactococcus lactis on Growth Performance, Immune Response, Gut Histology and Immune-Related Genes in Whiteleg Shrimp, Litopenaeus vannamei. Microorg., 8(281): $15 \mathrm{pp}$.

Ziaei-Nejad, S.; Rezaei, M.H.; Takami, G.A.; Lovett, D.L.; Mirvaghefi, A.R.b and Shakouri, M. (2006). The effect of Bacillus spp. bacteria used as probiotics on digestive enzyme activity, survival, and growth in the Indian white shrimp Fenneropenaeus indicus. Aquacult., 252: 516-524.

Zivkovic, R. (1999). Probiotics of microbes against microbes. Acta Medica Croatica 53, 23-28. Burford, M.A., Thompson, P.J., Mcintosh, R.P., Bauman, R.H. And Pearson, D.C. 2004. The contribution of flocculated material to shrimp (Litopenaeus vannamei) nutrition in a high-intensity, zero-exchange system. Aquacult., 232 (1-4): 525-537.

Zorriehzahra, M. J.; Delshad, S. T.; Adel, M.; Tiwari, R.; Karthik, K.; Dhama, K. and Lazado, C. C. (2016). Probiotics as beneficial microbes in aquaculture: an update on their multiple modes of action: a review. Veter. Quart., 36(4): 228-241. 